\title{
ORYGENES I HEBRAJSKI TEKST PISMA ŚWIĘTEGO
}

Orygenes pozostaje niewątpliwie najbardziej wszechstronnym egzegetą w dziejach Kościoła, budzącym ciaggle podziw i stanowiącym źródło inspiracji dla kolejnych pokoleń teologów ${ }^{1}$. Na pewno wspiął się na szczyt egzegezy w epoce patrystycznej. Słusznie zanotował Henri Crouzel: „Orygenes słynie przede wszystkim ze swej egzegezy duchowej i alegorycznej. [...] Nie należy wszakże zapominać, że jest również, obok Hieronima, największym w chrześcijańskiej starożytności mistrzem egzegezy krytycznej i literalnej"2. Z racji tej wszechstronności także zagadnienia dotyczące księgi i tekstu biblijnego znalazły w dziele Orygenesa bardzo adekwatne usytuowanie połączone z głęboką refleksją teologiczną, zwłaszcza z jego chrystologią i eklezjologią․ Jako gramatyk i erudyta, filozof $i$ teolog kontemplatyk, nieustannie szukał on znaczenia słowa natchnionego, zestawiając ze sobą wypowiedzi biblijne, zagłębiając się w nie i szukając ich coraz pełniejszego znaczenia. Formacyjnie i duchowo wywodził się z Aleksandrii z początku III w. i tam ze swej strony zaproponował „katechezę", która właściwie biorąc była szkołą filozofii ${ }^{4}$. W późniejszym okresie udał się do Palestyny, a w końcu w 230 r. osiadł w Cezarei. Był to dla Orygenesa swoisty ,powrót do źródeł”, ponieważ tam żył Chrystus i tam relacje między wspólnotami żydowskimi i chrześcijańskimi układały się stosunkowo harmonijnie. Rabini i nauczyciele z jednej strony, a biskupi

${ }^{*}$ Ks. dr hab. Janusz Królikowski, prof. UPJPII - kierownik Katedry Teologii Dogmatycznej na Wydziale Teologicznym Sekcja w Tarnowie Uniwersytetu Papieskiego Jana Pawła II w Krakowie; e-mail: jkroliko@poczta.onet.pl.

${ }^{1}$ Niniejsze opracowanie stanowi kontynuację wcześniejszego opracowania: J. Królikowski, Początki chrześcijańskiego tekstu Pisma Świętego, VoxP 37 (2017) t. 67, 259-276.

${ }^{2}$ H. Crouzel, Orygenes, thum. J. Margański, Kraków 2004, 93. Por. R. Heine, Reading the Bible with Origen, w: The Bible in Greek Christian Antiquity, Notre Dame 1997, 131-148.

${ }^{3}$ Por. H. de Lubac, Histoire et Esprit. L'intelligence de l'Écriture d'après Origène, Paris 1950; H.U. von Balthasar, Parole et Mystère chez Origène, Paris 1957.

${ }^{4}$ Por. A. Le Boulluec, L' «école» d'Alexandrie. II. Origène, w: Histoire du christianise, t. 1: Le Nouveau Peuple (des origines à 250), sous la derection de J.-M. Mayeur - Ch. et L. Pietri-A. Vauchez - M. Venard, Paris 2000, 557-576. 
i kaznodzieje z drugiej strony spotykali się ze sobą niemal na co dzień, podejmując podstawowe problemy dotyczące wiary i teologii ${ }^{5}$.

Orygenes był przede wszystkim człowiekiem Kościoła - ecclesiasticus $v i r^{6}$ - kapłanem i kaznodzieją, dlatego też tekst Septuaginty, jako podstawowy tekst eklezjalny, stanowił dla jego badań egzegetycznych punkt odniesienia, cieszący się uprzywilejowaną pozycją i domagający się obrony teologicznej. Warto zauważyć, że właśnie w kontekście zagadnienia interpretacji Biblii Orygenes wyraził swoje głębokie pragnienie bycia człowiekiem Kościoła:

„Ja [...] pragnę być człowiekiem Kościoła [...] ja przez uczynki i myśli swoje pragnę być i nazywać się chrześcijaninem, jednakowego sensu szukam w Starym i w Nowym Testamencie"7.

Podróże, które zaprowadziły go do Rzymu, potem do Azji, a przede wszystkim do Palestyny, oraz łączące się z nimi spotkania i doświadczenia, ubogaciły jego nieustanne poszukiwania duchowe i teologiczne, prowadząc go także do refleksji nad poważnym zagadnieniem paralelnego istnienia i realnego funkcjonowania dwóch tekstów biblijnych, to znaczy chrześcijańskiego i żydowskiego. Niemal całe życie zmagał się z tym problemem, dochodząc do osobistej syntezy właściwie dopiero pod koniec życia. Wiele faktów pozwala stwierdzić, że w swoich kolejno formułowanych wypowiedziach Orygenes był zarazem wnikliwy i odważny ${ }^{8}$. W tym miejscu interesuje nas jednak przede wszystkim stosunek Orygenesa do hebrajskiego tekstu Biblii.

1. Pierwszeństwo Septuaginty. Pierwszy tekst, który należy zauważyć u Orygenesa w ramach podejmowanego tutaj zagadnienia, znajduje się w liście Orygenesa do Juliusza Afrykańczyka i dotyczy „dziejów Zuzanny”:

„Czy może należałoby więc wyeliminować przykłady wykorzystywane w Kościołach i nakazać wspólnocie porzucenie używanych przez nią ksiąg świętych oraz pochlebiać żydom i skłonić ich, aby dali nam, w miejsce tych tekstów, teksty czyste, które nie zawierają niczego «wyprodukowanego»? Czy Opatrzność, dostarczając w świętych Pismach zbudowania dla wszystkich Kościołów Chrystusa, nie zatroszczyła się o tych, którzy «zostali nabyci za wielką cenę», o tych, «za których umarł Chrystus»? [...] Nie mówię tego,

\footnotetext{
${ }^{5}$ Por. H. Bietenhard, Caesarea, Origenes und die Juden, Stuttgart 1974; N. de Lange, Origen and the Jews, Cambridge 1976.

${ }^{6}$ Origenes, Homiliae in Lucam 2, 2, éd. H. Crouzel - F. Fournier - P. Périchon, SCh 87, Paris $1962,110$.

${ }^{7}$ Tamże 16, 6, SCh 87, 244, thum. S. Kalinkowski: Orygenes, Homilie o Ewangelii św. Łukasza, PSP 36, Warszawa 1986, 76.

${ }^{8}$ Por. D. Barthélemy, Origène et le texte de l'Ancien Testament, w: Epektasis. Mélanges patristiques offerts au Cardinal Daniélou, Paris 1972, 247-261; C.P. Bammel, Law and Temple in Origen, w: Templum amicitiae. Essays on the Second Temple Presented to E. Bammel, Sheffield 1991, 464-476.
} 
że odrzucałbym badanie Pism według żydów i porównanie z nimi naszych Pism. [...] Czynię to do dawna. [...] Starajmy się jednak nie ignorować ich tekstów, aby nie musieć - gdy rozmawiamy z żydami - przywoływać tego, co znajduje się u nich, nawet jeśli tego nie ma w naszych księgach. Jeśli bowiem zyskamy tak dobre przygotowanie, by dyskutować z nimi, nie będą nas lekceważyć, ani - jak zazwyczaj czynią - szydzić z wierzących pochodzących z pogan, mówiąc, że nie znają oni autentycznych lekcji zawartych w ich tekstach"9.

Orygenes zdaje się w swoim postępowaniu iść droga wytyczoną wcześniej przez św. Justyna - pozornie jest nastawiony polemicznie, ale cel, który sobie stawia, ma przede wszystkim charakter taktyczny. Grecki tekst Septuaginty ma dla niego charakter eklezjalny, a tym samym stanowi pewną normę myślenia i postępowania - nie jest jego prywatnym tekstem, którym mógłby się swobodnie posługiwać. W tym samym liście do Juliusza Afrykańczyka stwierdza z naciskiem: „Studiowałem szczególnie tłumaczenie Siedemdziesięciu, aby nie umniejszyć w niczym roli Kościołów, które są pod niebem" "10. Następnie Orygenes przywołuje - ma to dla niego bardzo duże znaczenie - konkretne przykłady, które sprawiły, że żydzi narazili na szwank swoją wiarygodność, ponieważ w starożytności usunęli oni z Pism wszelkie aluzje do zabicia proroków:

„Oni [żydzi] pozbawili lud wszelkiej wiedzy, na ile było to dla nich możliwe, eliminując wszelkie wypowiedzi mówiące o potępieniu starszych, przywódców i sędziów, chociaż coś na ten temat zachowało się w apokryfach. Podam jako przykład to, co opowiada się o Izajaszu i jest poświadczone w Liście do Hebrajczyków, nawet jeśli nie zostało napisane w żadnej z ogłoszonych ksiag"11.

Mimo tej wypowiedzi i wyrażonego w niej dystansu w stosunku do żydów, Orygenes chce przygotować się do debaty z nimi, przyjmując za jej podstawę wspólny z nimi „korpus literacki”, to znaczy żydowski zbiór ksiąg świętych, który domagał się pokonania trudności wynikającej z różnorodności języków i z różnych wariantów obecnych w rozmaitych tekstach. Opierając się na tym założeniu, chrześcijanie wywodzący się ze środowisk pogańskich, a stanowili oni zdecydowaną większość, uniknęliby oskarżenia o ignorancję ze strony interlokutorów wywodzących się z judaizmu. Był to na pewno argument o charakterze negatywnym, ale mimo to posiada on dużą wymowę, ponieważ Orygenes łączy go z elementem pozytywnym, przede wszystkim z aspektem symbolicznym, to znaczy uczciwym uwzględnieniem liczby dwudziestu dwóch ksiagg, które stara tradycja łączyła z żydowskim korpusem Pism:

${ }^{9}$ Orygenes, Epistula ad Iulium Africanum 8-9, éd. N. de Lange, SCh 302, Paris 1983, 532-534, thum. własne.

${ }^{10}$ Tamże 9, SCh 302, 534, thum. własne.

${ }^{11}$ Tamże 13, SCh 302, 543, thum. własne. 
„Trzeba wiedzieć, że według tradycji żydowskiej są dwadzieścia dwie księgi Starego Testamentu, tyle ile liter alfabetu hebrajskiego"'2.

Powołując się w innym miejscu na zawartą w tym stwierdzeniu klasyczną tradycję, Orygenes dodaje interesujący komentarz. Nawiązując do dawnej tradycji religijnej, nadaje żydowskiemu i narodowemu znaczeniu liczby dwadzieścia dwa perspektywy uniwersalne:

„Nie należy zapominać, że jeśli według tradycji żydowskiej są dwadzieścia dwie księgi Testamentu - liczba, która pokrywa się z liczbą liter ich alfabetu - to nie jest to pozbawione znaczenia. Jak dwadzieścia dwie litery stanowią wprowadzenie do mądrości i do nauki boskich Pism w znakach używanych przez ludzi, tak i dwadzieścia dwie księgi natchnione stanowią wprowadzenie do mądrości Bożej i do poznania rzeczy"13.

Zainteresowanie Pismami żydowskimi sprawiło, że Orygenes jest bezpośrednim świadkiem żydowskiego wykazu ksiąg świętych. Przywołajmy tutaj za Euzebiuszem z Cezarei początek i koniec wykazu podanego według podwójnego nazewnictwa: jedno przywołuje greckie tytuły Septuaginty, poświadczone już przez Filona z Aleksandrii w odniesieniu do Prawa Mojżeszowego, a drugie opiera się na transliteracji tytułów żydowskich, czyli incipitów - pierwszych słów ksiąg:

„Te dwadzieścia dwie księgi są według żydów następujące: ta, którą my nazywamy Księgą Rodzaju, a żydzi od pierwszego słowa księgi Beresith, to znaczy «Na początku», Księga Wyjścia - Ouellesmot, czyli «To są imiona», Księga Kapłańska..."14.

W przywołanym tekście Orygenes jawi się jako obiektywny świadek tradycji żydowskiej dotyczącej korpusu ksiąg świętych. Sposób jednak, w którym mówi: ,według żydów” lub ,według nich” w innych tekstach, w przeciwieństwie do „naszych Pism”, pokazuje, że w chwili, w której pisze, sprawa w tradycji żydowskiej nie jest jeszcze całkowicie przesądzona. Zachowuje on i dokumentuje liczbę dwadzieścia dwa, a nie dwadzieścia cztery, jak czynią inni autorzy chrześcijańscy ${ }^{15}$. Dodaje do wykazu nazewnictwo żydowskie, a sprecyzowanie liczby ksiąg pokazuje dystans istniejący między żydami i chrześcijanami - są to dwa częściowo odrębne kierunki identyfikacji pism. Nie przeszkadza to jednak w uznaniu ze strony chrześcijańskiej istnienia i dopuszczalności wersji greckich innych niż Septuaginta, będących efektem

${ }^{12}$ Tenże, Commentaria in Psalmos 1, w: Eusebius Caesariensis, HE VI 25, 1, ed. i tłum. ŹMT 70 [wyd. grecko-polskie, oprac. H. Pietras, thum. A. Caba na podstawie thum. A. Lisieckiego], Kraków 2013, 429.

${ }^{13}$ Tenże, Philocalia 3, éd. M. Harl, SCh 302, 260, thum. własne.

${ }^{14}$ Eusebius Caesariensis, HE VI 25, 2, ŹMT 70, 429.

${ }^{15}$ Por. A. Paul, Genèse et avènement des «Écritures» chrétiennes, w: Histoire du christianise, t. 1: Le Nouveau Peuple, s. 700-708. 
prowadzonej od dłuższego czasu działalności żydowskiej. Dla Orygenesa był to sposób uznania rangi tekstu żydowskiego, za którym starały się blisko iść inne wersje, podobnie jak postępowała Septuaginta. W komentarzu Orygenesa do Ewangelii św. Mateusza znajdujemy bardzo wymowne stwierdzenia:

„Otóż rozbieżności między rękopisami Starego Testamentu zdołaliśmy z pomocą Bożą zaradzić posługując się świadectwem pozostałych wydań. Te bowiem miejsca w Septuagincie, które z powodu rozbieżności rękopisów budziły wątpliwość, poddaliśmy ocenie na podstawie pozostałych wydań i zgodne z nimi zachowaliśmy, zaznaczając obelosem ${ }^{16}$ te, których brak w tekście hebrajskim (nie mieliśmy odwagi usunąc ich całkowicie), a inne dodaliśmy ze znakiem asterysku, aby było widoczne, że lekcje nie występujące w Septuagincie dodaliśmy z pozostałych, zgodnych z tekstem hebrajskim wydań"17.

Mimo wszystko Orygenes pozostaje bezwarunkowo przywiązany do wersji Septuaginty, o czym - jako racja pierwszorzędna - decyduje jego wierność Kościołowi, który posługuje się właśnie Septuagintą. Jest on mimo to bardzo zainteresowany żydowskim tekstem Pisma, tak jak i wersjami greckimi, które narodziły się w środowiskach żydowskich po dokonanej rewizji tekstu. Decydowały o tym rozmaite racje. W dziełach teologicznych i w homiliach Orygenes często cytuje księgi, które w późniejszym okresie zostaną nazwane deuterokanonicznymi, a które pierwszorzędnie zostały przyjęte i rozpropagowane za pośrednictwem Septuaginty. Nie przeszkadza mu to jednak wyrazić pewnych zastrzeżeń, oczywiście rzadkich, odnośnie do statusu tekstów nieobecnych w korpusie żydowskim. Potwierdza w ten sposób swoją zależność od praktyki przyjętej i rozpowszechnionej w Kościołach posługujących się językiem greckim. W literaturze, która jest tego świadkiem, oczywiście w tej, która do nas dotarła, księgi deuterokanoniczne nie były przedmiotem komentarza lub homilii dla Orygenesa. Jego pisma zawierają aluzje do uwag krytycznych, z którym spotkało się jego przepowiadanie w Cezarei - zarzucano mu między innymi, że posługuje się wersjami greckimi Pisma, różniącymi się od wersji Septuaginty. Być może z tego powodu musiał zrezygnować z tej działalności. Nie wydaje się, aby Orygenes kiedykolwiek podjął się komentowania ksiagg nie należących do zbioru żydowskiego i jest prawdopodobne, że te księgi nie były czytane w zgromadzeniach chrześcijańskich w Cezarei, gdzie pełnił funkcję kaznodziei i nauczyciela. Jest to wymowne świadectwo wpływu wywieranego przez żydowski zestaw świętych Pism i ich wykorzystania w środowisku chrześcijańskim. Ksiega Hioba, Kohelet i Pieśń nad pieśniami były czytane i komentowane, ale nie Księgi Mądrości i Syracydesa. Dobór czytań, którym posługiwali się żydzi w synagodze, nie pozostawał bez wpływu na liturgię chrześcijańską. Można powiedzieć ogólniej, pomijając aspekty

\footnotetext{
${ }^{16}$ Obelos - kreska pozioma - znak diakrytyczny dla oznaczenia nieautentycznego ustępu.

${ }^{17}$ Origenes, Commentarium in Evangelium Matthaei 15, 14, PG 13, 1293, thum. K. Augustyniak: Orygenes, Komentarz do Ewangelii wedtug Mateusza, ŹMT 10, Kraków 1998, 246-247.
} 
taktyczne i polemiczne, że uwaga zwrócona po Justynie na kanoniczne Pisma żydowskie tworzyła korzystne warunki dla ich uznania obiektywnego i dla ich przyjęcia w Kościele. Stawały się one podstawą debaty z żydami, czyli traktowano je bardzo poważnie. Orygenes nie tylko nie opiera się tej tendencji, ale poszedł jeszcze dalej. Świadczą o tym wprowadzone przez niego innowacje, między innymi zapoczątkowanie krytyki tekstualnej Pism świętych, do czego wykorzystał swoje przekonania i swoją wiedzę. Jego przedsięwzięcie w tej materii pozwala na wyprowadzenie bardzo ciekawych wniosków.

2. Heksapla. Orygenes, biblista i gramatyk, podjął się zbudowania monumentu literacko-biblijnego nazywanego Heksapla (,sześciokształtna”) ${ }^{18}$. $\mathrm{Z}$ tego ogromnego dzieła liczącego około 6500 stron, na których zostały zebrane i porównane pozostające do dyspozycji Orygenesa różne wersje Pisma zachowały się tylko nieliczne fragmenty. Euzebiusz z Cezarei jest pierwszym świadkiem sposobu pracy i struktury dzieła dokonanego przez Orygenesa:

„Z taką dokładnością zabrał się Orygenes do badania Pisma Świętego, że nauczył się języka hebrajskiego i nabył na własność teksty oryginalne, którymi posługiwali się żydzi, a pisane po hebrajsku. Szukał ponadto wydań tych tłumaczy, którzy niezależnie od przekładu Septuaginty thumaczyli księgi święte, i znalazł inne tłumaczenie, różniące się od ogólnie znanych przekładów Akwili, Symmacha i Teodotiona, i wydobył je na światło dzienne z nie wiem jakich zakamarków, gdzie od dawna leżały ukryte. Ponieważ nie widział, czyje to były przekłady, zaznaczył tylko, że jeden z nich znalazł w Nikopolis pod Akcjum, drugi natomiast w jakiejś innej miejscowości. W Heksaplach Psalmów umieścił nie tylko piąte, ale także szóste i siódme tłumaczenie, a o jednym z nich mówi, że w czasach Antonina [Karakalli], syna Sewera, znalazł je w Jerychu, w beczce. Wszystkie te przekłady zebrał w jednej księdze, podzielił je na okresy zdaniowe, zestawił razem obok siebie z tekstem hebrajskim i tak pozostawił nam rękopis zwany Heksapla. Oprócz tego osobno w Tetraplach opracował wydanie Akwili, Symmacha i Teodotiona razem z Septuagintą"19.

Przywołany tekst Euzebiusza obfituje w bardzo precyzyjne uwagi, chociaż domagają się one weryfikacji. Wypowiedź zamierza być pochwałą Orygenesa, ukazującą wielkość dzieła, którego się podjął i które doprowadził do końca. Euzebiusz nie podaje jednak daty i miejsca opracowania Heksapli, jak to ma miejsce w przypadku przedstawiania komentarzy biblijnych wielkiego egzegety. Pojawia się więc przynajmniej kilka pytań.

Gdzie i kiedy Orygenes opracował tę imponującą synopsę, która według świadectwa Euzebiusza obejmowała: tekst hebrajski Pism i jego transliterację

${ }^{18}$ Por. Origen's Hexapla and Fragments. Papers Presented at the Rich Seminar on the Hexapla. Oxford Center for Hebrew and Jewish Studies $25^{\text {th }}$ July $-3^{\text {th }}$ August 1994, ed. A. Salvesen, Tübingen 1998.

${ }^{19}$ Eusebius Caesariensis, HE VI 16, 1-4, ŹMT 70, 413. 
grecka, wersję grecką Septuaginty przyjętą przez chrześcijan, wersje greckie Akwili, Symmacha i Teodocjona opracowane przez żydów, aby skorygować różnice i braki Septuaginty oraz trzy dodatkowe przekłady Psalmów? Jest możliwe, że dzieło zostało zapoczątkowane przez Orygenesa jeszcze w Aleksandrii. Znał on rozmaite prace prowadzone przez tamtejszych grammatikoi oraz metodę krytyczną zastosowaną przez Arystarcha (uznawanego za ojca krytyki tekstualnej) do wydania Homera ${ }^{20}$. Nie należy więc dziwić się, że jako grammatikos postanowił przygotować własną edycję ksiąg świętych, chociaż jej rozmach każe dostrzec, że było to imponujące przedsięwzięcie. Mógł potem przez kilka lat kontynuować swoją pracę w Cezarei, prowadząc ją do końca. Euzebiusz opisał, w jaki sposób było zorganizowane skryptorium z siedmioma tachygrafami, którzy wymieniali się, tyleż kopistów i dziewcząt sprawnych w kaligrafii, przy czym utrzymanie wszystkich zostało zapewnione przez przyjaciela dobroczyńcę - Ambrożego ${ }^{21}$.

W Aleksandrii Orygenes korzystał z kompetentnej i ofiarnej współpracy nawróconego żyda pochodzącego z Palestyny, nazywanego „Żydem”, który pomagał mu w pracach nad tekstem hebrajskim. Czy Orygenes znał hebrajski? A jeśli tak, to na ile go opanował? Euzebiusz wprawdzie wspomina o znajomości hebrajskiego przez Orygenesa, ale specjaliści dyskutują na ten temat. Podobnie jak Filon, Orygenes prawdopodobnie nie znał go w większym zakresie, dlatego też potrzebował wykwalifikowanej pomocy.

Co rzeczywiście obejmowała Heksapla? Podstawą i tekstem stanowiącym punkt odniesienia była Septuaginta, wersja kościelna odgrywająca uprzywilejowaną rolę, niekiedy także weryfikującą w stosunku do innych tekstów. Czy jednak Orygenes posługiwał się wersją wykorzystywaną w Aleksandrii czy w Cezarei? Przekazywana z pokolenia na pokolenie bez jakiejś specjalnej troski Septuaginta wymagała już uzupełnienia o wyjaśniające ją znaki diakrytyczne oraz komentarze. Domagało się tego zabiegu także zestawianie Septuaginty z tekstem żydowskim oraz wersjami greckimi przeznaczonymi dla żydów. Pojawia się także pytanie, czy Orygenes w kolumnie przeznaczonej dla Septuaginty w swojej synopsie nie wykorzystał wersji, którą już wcześniej opracował dla swoich potrzeb. Kwestia jest przedmiotem debaty, chociaż najlepsi znawcy zagadnienia zdają się dzisiaj opowiadać za drugą hipotezą 22 . Zakładamy zatem, że Orygenes przygotował swoją edycję Septuaginty zanim przystapił do opracowywania Heksapli.

${ }^{20}$ Por. E. Würthwein, The Text of the Old Testament. An Introduction to the Biblia Hebraica, Grand Rapids 1995, 57-58.

${ }^{21}$ Por. Eusebius Caesariensis, HE VI 23, 1, ŹMT 70, 425.

${ }^{22}$ Por. O. Munnich, Les Hexaples d'Origène à la lumière de la tradition manuscrite de la Bible grecque, w: Origeniana sexta. Origène et la Bible / Origen and the Bible. Actes du Colloquium Origenianum Sextum, Chantilly, 30 août - 3 septembre 1993, ed. G. Dorival - A.L. Boulluec, Louvain 1995, 174-177. 
Ile kolumn zawierała słynna synopsa? Utrwalone określenie Heksapla ( $\tau \grave{\alpha}$ $\dot{\varepsilon} \xi \alpha \pi \lambda \hat{\alpha})$ wskazuje, że było ich sześć. Tę liczbę podaje także Euzebiusz z Cezarei. Fragmenty manuskryptów, które przetrwały do naszych czasów, pomijają jednak pierwszą kolumnę $\mathrm{z}$ tekstem hebrajskim zapisanym za pomocą liter hebrajskich. Kolumna obok, druga według Euzebiusza, miała zawierać transliterację pierwszej za pomocą liter greckich, tak żeby czytelnicy niewprawni w hebrajskim, łącznie z Orygenesem, mogli czytać tekst bez popełniania błędów wokalnych. Cztery pozostałe kolumny, od lewej do prawej, zawierały wersje Akwili (trzecia), Symmacha (czwarta), Septuagintę przepracowaną przez Orygenesa i nazywaną ,wersją Heksapli” (piąta) i Teodocjona (szósta). Taki był zasadniczy układ całej synopsy. Jako okazjonalne uzupełnienie, jak w przypadku psalmów, mogły być uwzględnione inne wersje greckie na osobnych kolumnach, ale ich obecność jest jeszcze przedmiotem dyskusji, ponieważ odzyskane resztki materialne należały do kopii pochodzących z późniejszych wieków, odległych od Orygenesa, gdy kopiści nie mieli już żadnych argumentów przemawiających za zachowaniem kolumny hebrajskiej. Dla Orygenesa, który szukał oryginalnego tekstu Pisma, była ona natomiast konieczna. Można więc zasadnie opowiedzieć się za liczbą sześć, nie wykluczając, że tekst zapisany w języku hebrajskim hebrajskimi literami stanowił osobny egzemplarz, pełniący funkcję pierwszej kolumny.

Jaka relacja zachodzi między Heksapla w sześciu kolumnach (wersjach) a Tetrapla w czterech kolumnach? Są tacy, którzy uważają, że Tetrapla stanowi wersję mniejszą (editio minor) Heksapli. Można wyobrazić sobie, że Orygenes zaczął swoje dzieło od opracowania synopsy w czterech kolumnach, w których znajdowały się wersje Akwili, Symmacha, Septuaginta i Teodocjo$\mathrm{na}^{23}$. W Cezarei mogły one zostać potem uzupełnione o kolejne dwie kolumny.

Orygenes przygotowując swoje dzieło krytyczne oparł się na metodzie przyjętej przez grammatikoi w Aleksandrii, przedstawiając swoją wersję Septuaginty z dokonana przez siebie rewizją tekstu - zachodziła potrzeba posiadania najlepszej, czyli najpewniejszej redakcji oficjalnego tekstu Kościoła. Orygenes dostarczył tekstu - jak wynika z wyżej cytowanej wypowiedzi zaopatrzonego w przyjęte znaki diakrytyczne. Asteryskami oznaczył więc niejasności w stosunku do tekstu hebrajskiego i najwierniejszych wersji oraz zestawił je ze sobą. Dodatki wyróżnił za pomocą obelosów. W swoich licznych komentarzach biblijnych Orygenes zachował zwyczaj wykorzystywania potocznego tekstu Septuaginty, a nie tekstu, który osobiście opracował i włączył do Heksapli. Oczywiście, nawiązywał w swoich wypowiedziach także do innych wersji komentowanego tekstu biblijnego, ale traktował je raczej pomocniczo. Korzystanie z tak opracowanego tekstu biblijnego, naznaczonego dwuznacznościami, wywarło potem bardzo negatywne skutki na tradycję

${ }^{23}$ Por. B. Botte - P.-M. Bogaert, Septante et versions grecque, w: Supplément au Dictionnaire de la Bible, t. 12, Paris 1993, 559-565. 
rękopiśmienną ${ }^{24}$, ponieważ niektórzy kopiści pomieszali zapisane obok siebie teksty, inni pousuwali niezrozumiałe dla nich znaki diakrytyczne, a niekiedy wyrzucili także teksty zaznaczone za pośrednictwem obelosów. Orygenes, nie mając oczywiście takiego zamiaru, wywołał poważne zamieszanie, a jego wielka praca wykonana na rzecz następców, okazała się właściwie nieużyteczna. W 683 r. muzułmanie zdobyli Cezareę, a w efekcie tego wydarzenia uległy rozproszeniu zasoby miejscowej biblioteki, wśród których znajdowały się manuskrypty Orygenesa.

Dzieło, którym była Heksapla, zasługuje na ocenę w świetle całego wielkiego dzieła egzegetycznego dokonanego przez Orygenesa. Zwraca ono przede wszystkim uwagę, że szukając rozumienia tekstów świętych należy uwzględniać dwa głosy biblijne. Na pierwszym miejscu sytuuje się oczywiście Septuaginta jako Pismo Święte żyjące w Kościele i dla Kościoła. Jako gorący i odpowiedzialny chrześcijanin, Orygenes chciał zachować za wszelką cenę jej pierwszeństwo, mając na uwadze opatrznościową ekonomię zbawienia, którą ta wersja przekazuje oraz poucza, w jaki sposób chrześcijanin może z niej czerpać nowe życie i w nim uczestniczyć, dążąc do zbawienia. Na drugim miejscu sytuuje się głos, który rozbrzmiewa ze zbioru pism posiadanych przez żydów, mających charakter weryfikujący, a niekiedy także wyjaśniający. Do tego zbioru Orygenes odwołuje się jako uczony, który szuka źródeł tradycji kościelnej i stara się ją lepiej rozumieć. Dające się łatwo zauważyć u niego „napięcie" między zdecydowanie zamierzonym poszukiwaniem pierwotnej prawdy hebrajskiej i akceptacją dwoistości, a nawet wielości świadectw biblijnych, jest tylko pozorne. Nie przykłada do tej wielości miary hierarchicznej, to znaczy nie stara się określić pierwszeństwa takiego czy innego tekstu. Nie zastanawia się także nad genezą poszczególnych tekstów Biblii, w czym jest bardzo bliski innym Ojcom greckim ${ }^{25}$. Trzymali się oni ogólnej zasady, że każdy tekst biblijny ma coś do powiedzenia wierzącym i nie powstał przypadkowo. Należy ponadto zauważyć, że pomija on słynną legendę o siedemdziesięciu tłumaczach zapisaną w liście Arysteasza. Jeśli uwzględni się, że były to pierwsze dziesięciolecia trzeciego wieku, to jego postępowanie jawi się jako wyjątkowe i wzorcowe. Tym, co wyróżnia więc Orygenesa, jest równoległe i dopełniające się uwzględnianie dwóch sposobów postępowania, to znaczy „wewnątrzkościelnego" i naukowego.

3. Utrwalenie znaczenia Septuaginty. Grecka Septuaginta została uznana za chrześcijańską wersję Starego Testamentu już na długo przed Orygenesem. Po przyznaniu wolności chrześcijaństwu, a potem po uznaniu go za

${ }^{24}$ Por. E. Ulrich, Origen's Old Testament Text. The Transmission History of the Septuagint to the Third Century C.E., w: Origen of Alexandria. His World and His Legacy, ed. Ch. Kannengiesser - W.L. Peterson, Notre Dame 1988, 3-33.

${ }^{25}$ Por. M. Harl, La langue de Japhet. Quinze études sur la Septante et le grec des chrétiens, Paris 1992, 265. 
religię państwową, taka sytuacja została zalegalizowana przez cesarza Justyniana w słynnej noweli 146. peri Hebraion (de Hebraeis) z 8 lutego 553 roku $^{26}$. Ustawa zabraniała czytania ksiąg żydowskich w synagogach i polecała żydom, aby używali Pisma Świętego w języku greckim, czyli Septuaginty, podkreślając jej charakter natchniony i prorocki. Oznaczało to, że między tekstem żydowskim i jego odpowiednikiem helleńskim zachodzi tożsamość w odniesieniu do jego źródła i do jego treści oraz że między Septuagintą i tradycją żydowską nie ma zerwania. Justynian pozwalał żydom także na czytanie wersji Akwili, mimo że zwierała ona warianty tekstowe niezgodne z tradycją chrześcijańską. Przyjęcie Septuaginty ze strony Kościoła weszło w ten sposób do prawodawstwa państwowego, choć w rzeczywistości nie tworzyło jakiejś nowej sytuacji. W każdym razie był to na pewno ważny akt dokonującego się w starożytności schrystianizowania Septuaginty.

W środowisku żydowskim nowela Justyniana wywołała sprzeciw, przyczyniając się do zradykalizowania przywiązania do tekstu hebrajskiego, jak miało to już miejsce w okresie pierwszej konfrontacji żydów z chrześcijaństwem, która zakończyła się odrzuceniem Pism greckich jako takich. Oczywiście, stopniowe dystansowanie się w stosunku do tekstu greckiego pojawiło się już w okresie przedchrześcijańskim. Pierwsze rewizje tekstu Septuaginty miały miejsce w I w. prz. Chr.: Żyd Filon, a następnie św. Justyn męczennik zdają się niekiedy cytować tekst przejrzany. W II w. w społeczności żydowskiej utrwalała się tendencja do weryfikowania różnych fragmentów w Pismach greckich w odniesieniu do dominującego tekstu masoreckiego. Później pojawiła się u żydów tendencja do głębszego przejrzenia wersji greckiej ,aleksandryjskiej", ponieważ stopniowo stawała się ona wersją chrześcijańską. Rewizje tekstu stały się systematyczne, co było istniejącym jeszcze wyrazem przekonania, że prawda ksiąg świętych w wersji greckiej nie jest tylko ekskluzywnie chrześcijańska. Postępująca praktyka rewizji tekstu greckiego doprowadziła do pojawiania się nowych wersji Biblii greckiej pod kontrolą żydowską. Św. Justyn poświadcza, że w Rzymie posługiwano się wersją Akwili, a św. Ireneusz wspomina wersje „Teodocjona z Efezu” i „Akwili z Pontu”27. Dojdzie do tego wersja Symmacha mniej dosłowna, ale bardziej literacka od wersji poprzednich - niestety, zachowała się tylko w nielicznych fragmentach. Istniały też inne wersje $\mathrm{e}^{28}$. Orygenes dysponował tymi wersjami Pisma żydowskiego w języku greckim w Tetrapli i Heksapli, co świadczy, że nie tylko były jakoś znane w środowisku chrześcijańskim, ale że budziły zainteresowanie i brano je pod uwagę w nauczaniu chrześcijańskim i w teologii.

\footnotetext{
${ }^{26}$ Por. G. Veltri, Die Novelle 146 ,,peri Hebraiôn”. Das Verbot des Targumvortrags in Justinians Politik, w: Die Septuaginta zwischen Judentum und Christentum, hrsg. M. Hengel - A.M. Schwemer, Tübingen 1994, 116-130.

${ }^{27}$ Irenaeus, Adversus haereses III 21, 1, éd. A. Rousseau - L. Doutreleau, t. 2: Livre III, SCh 211, Paris 1974, 398. Por. Eusebius Caesariensis, HE V 8, 10, ŹMT 70, 331.

${ }^{28}$ Por. M. Harl - G. Dorival - O. Munnich, La Bible Grecque des Septante, Paris 1988, 156-161.
} 
Wielka szkoda, że w późniejszym okresie, zwłaszcza pod wpływem tradycji rabinistycznej, żydzi odrzucą zainteresowanie wersją grecką swoich Pism, od II w. opowiadając się coraz bardziej zdecydowanie za językiem hebrajskim jako ,językiem świętym”, a moment, w którym ich Pisma zostały przetłumaczone na język grecki, uznając za „dzień smutku”, jak czytamy w traktacie rabinicznym Soferim, przywoływanym w Talmudzie babilońskim ${ }^{29}$. Równie wielka szkoda, że i chrześcijanie po Orygenesie przez dłuższy czas nie będą się interesować wersją hebrajską Pisma Świętego, opowiadając się jednostronnie za Septuagintą. Trzeba będzie dopiero św. Hieronima, aby to zainteresowanie odżyło i stało się twórcze dla Kościoła i dla teologii.

\section{ORIGEN AND THE HEBREW TEXT OF THE BIBLE}

\section{(Summary)}

Origen is the exegete and Old Christian writer whose influence on the understanding of the Bible has always been determinative. Undoubtedly, for ecclesiastical reasons he deemed the Septuagint superior and regarded it as the Christian Old Testament. He thought highly of Hebrew text as well, which he often used for his research. An expression of this belief was among others the Hexapla worked out by Origen, which can be regarded as an exceptional manifestation of esteem towards the Old Testament and its Hebrew version. Origen's attitude towards the Bible can be characterized by two approaches: on the one hand it is the ecclesiastical approach which gives the first place to the text commonly accepted in the Church namely the Septuagint, but on the other hand he is open to every other text Hebrew or Greek, trying to understand it and take it into account in his commentary.

Key words: Bible, Septuagint, Origen, Hexapla, biblical text, Greek, Hebrew.

Słowa kluczowe: Biblia, Septuaginta, Orygenes, Heksapla, tekst biblijny, język grecki, język hebrajski.

\section{BIBLIOGRAFIA}

\section{Źródła}

Eusebius CAesariensis, Historia ecclesiastica, ed. i tłum. ŹMT 70 [wyd. grecko-polskie, oprac. H. Pietras, thum. A. Caba na podstawie tłum. A. Lisieckiego], Kraków 2013.

IREnAEus, Adversus haereses III, éd. A. Rousseau - L. Doutreleau, t. 2: Livre III, SCh 211, Paris 1974.

Origenes, Commentarium in Evangelium Matthaei, PL 13, 835-1600, thum. K. Augustyniak: Orygenes, Komentarz do Ewangelii wedtug Mateusza, ŹMT 10, Kraków 1998.

${ }^{29}$ Por. G. Veltri, Eine Tora für König Talmai. Untersuchungen zum Übersetzungsverständnis in der jüdisch-hellenistischen und rabbinischen Literatur, Tübingen 1994; uzupełniania i uwagi krytyczne w: E. Tov, The Greek and Hebrew Bible. Collected Essays on the Septuagint, Leiden 1999, 75-82. 
Origenes, Epistula ad Iulium Africanum, éd. N. de Lange, SCh 302, Paris 1983, 522-573.

Origenes, Homiliae in Lucam, éd. H. Crouzel - F. Fournier - P. Périchon, SCh 87, Paris 1962, tłum. S. Kalinkowski: Orygenes, Homilie o Ewangelii św. Łukasza, PSP 36, Warszawa 1986.

Origenes, Philocalia, éd. M. Harl, SCh 302, Paris 1983, 161-468.

\section{Opracowania}

Balthasar H.U. von, Parole et Mystère chez Origène, Paris 1957.

Bammel C.P., Law and Temple in Origen, w: Templum amicitiae. Essays on the Second Temple Presented to E. Bammel, Sheffield 1991.

Barthélemy D., Origène et le texte de l'Ancien Testament, w: Epektasis. Mélanges patristiques offerts au Cardinal Daniélou, Paris 1972, 247-261.

Bietenhard H., Caesarea, Origenes und die Juden, Stuttgart 1974.

Botte B. - Bogaert P.-M., Septante et versions grecque, w: Supplément au Dictionnaire de la Bible, t. 12, Paris 1993, 536-692.

Boulluec A. Le, L'«école» d'Alexandrie. II. Origène, w: Histoire du christianise, t. 1: Le Nouveau Peuple (des origines à 250), sous la derection de J.-M. Mayeur - Ch. et L. Pietri - A. Vauchez - M. Venard, Paris 2000, 557-576.

Crouzel H., Orygenes, tłum. J. Margański, Kraków 2004.

Harl M., La langue de Japhet. Quinze études sur la Septante et le grec des chrétiens, Paris 1992.

Harl M. - Dorival G. - Munnich O., La Bible Grecque des Septante, Paris 1988.

HeIne R., Reading the Bible with Origen, w: The Bible in Greek Christian Antiquity, Notre Dame 1997, 131-148.

Królikowski J., Początki chrześcijańskiego tekstu Pisma Świętego, VoxP 37 (2017) t. 67, 259-276.

LANGe N. De, Origen and the Jews, Cambridge 1976.

LuBAC H. DE, Histoire et Esprit. L'intelligence de l'Écriture d'après Origène, Paris 1950.

MunNich O., Les Hexaples d'Origène à la lumière de la tradition manuscrite de la Bible grecque, w: Origeniana sexta. Origène et la Bible / Origen and the Bible. Actes du Colloquium Origenianum Sextum, Chantilly, 30 août - 3 septembre 1993, ed. G. Dorival - A.L. Boulluec, Louvain 1995, 167-185.

Origen's Hexapla and Fragments. Papers Presented at the Rich Seminar on the Hexapla. Oxford Center for Hebrew and Jewish Studies $25^{\text {th }}$ July - $3^{\text {th }}$ August 1994, ed. A. Salvesen, Tübingen 1998.

Paul A., Genèse et avènement des "Écritures» chrétiennes, w: Histoire du christianise, t. 1: Le Nouveau Peuple (des origines à 250), sous la derection de J.-M. Mayeur - Ch. et L. Pietri - A. Vauchez - M. Venard, Paris 2000, 673-758.

Tov E., The Greek and Hebrew Bible. Collected Essays on the Septuagint, Leiden 1999.

Ulrich E., Origen's Old Testament Text. The Transmission History of the Septuagint to the Third Century C.E., w: Origen of Alexandria. His World and His Legacy, ed. Ch. Kannengiesser - W.L. Peterson, Notre Dame 1988, 3-33.

Veltri G., Die Novelle 146 ,,peri Hebraiôn”. Das Verbot des Targumvortrags in Justinians Politik, w: Die Septuaginta zwischen Judentum und Christentum, hrsg. M. Hengel - A.M. Schwemer, Tübingen 1994, 116-130.

VelTRI G., Eine Tora für König Talmai. Untersuchungen zum Übersetzungsverständnis in der jüdisch-hellenistischen und rabbinischen Literatur, Tübingen 1994.

WürthweIn E., The Text of the Old Testament. An Introduction to the Biblia Hebraica, Grand Rapids 1995. 